\title{
多くの実験を交え理解の促進を目指した 初学の流体力学講義の実践
}

A Lecture Intending Promotion of Understanding on Fluid Dynamics for Freshmen through Novel Explanations and Experimental Demonstrations

\section{高 木 正 平 ${ }^{1}$}

Shohei TAKAGI

\begin{abstract}
Freshmen learn a lot of important formula and theorems in fluid dynamics. It is often observed that their understanding and application of those in conventional lecture are unsatisfied. In order to overcome such undesirable situation, many experiments related to fluid-dynamics contents were demonstrated intending promotion of understanding on the formula and theorems lectured. The present paper introduces a few contents of the lecture and reports the results of questionnaire filled out at the end of the lecture.
\end{abstract}

Keywords : Experimental Demonstration, Fluid Dynamics, Lift, Bernoulli Theorem, Energy Conservation, Roberval Balance, Communicating Tube

キーワード: 実験実証, 流体力学，揚力，ベルヌーイの定理，エネルギー保存，ロバーバルの天秤， 連通管

\section{1.はじめに}

理工系の学生は, なじみ深いニュートン力学の $3 つ$ の法則を始めとして, 多くの重要な公式や定理に出会 う。しかしそれらを正しく理解し，正しく適用できて いない場合も多々見受けられる。その代表的な例は， ベルヌーイの定理であろう。飛行機の揚力発生機構の 説明にしばしば登場するこの定理は，流体密度が一定 と見なせる場合には流体運動におけるエネルギーの保 存を表し，ある流線に沿って『速度が速くなると圧力 は低下し，逆に速度が小さくなると圧力は上昇する』 ことを説明している．多くの翼がそうであるようにそ の断面形状として，下面に比べて上面が膨らんでいる ことを前提として，速度が下面のそれより速いことが 合理的に説明できれば，上下面の圧力の差から揚力の 発生が説明できる。しかしながら，何故速度の差が生 じるかを合理的に説明する必要がある。この説明のた めに翼の前縁から分岐した流れが翼の後縁に同時に到 着するためには，道のりの長い上面の方が流れは速く ならなければならないとする『同時到着理論』がよく 使われる．分岐した流れは後縁に同時に到着しないこ とは流れの可視化写真 ${ }^{1)}$ で示されているだけでなく， 流れに対して迎え角を持たないが揚力は発生する薄い 円弧翼の場合には適用できない，また，作用と反作用

2012 年 2 月 27 日受付

※ 1 室蘭工業大学
を用いた説明 ${ }^{2)}$ も妥当でないことは翼前後の流線を可 視化した写真を見れば明らかである ${ }^{3)}$ 。これらとは異 なる別の合理的な説明 ${ }^{1)}{ }^{4)}$, 5) が求められる訳である.

一方, ベルヌーイの定理は, 運動のエネルギーと圧力 に加えて位置エネルギーの和が保存される公式に拡張 できるが, 圧力の変化が無視できる場合は, 質点の運 動のエネルギーと位置エネルギーの和が保存され，こ の定理は密度を質量に置き換えするだけで質点の力学 にも適用できる。棹天秤の釣り合いは，錘の支点から の距離と錘の質量を掛けたモーメントが等しい性質を 用いて解く方法が一般的である。 しかし，後述する口 バーバルの天秤や連通管にこの手法を適用した場合, 簡潔で合理的な説明は甚だ難しいが，エネルギーや仕 事の保存の法則を適用すると驚くほど簡潔に説明でき る.

筆者は本学工学部の一年生を対象としたオムニバス 形式の講義の中で『航空宇宙機を支える流体の性質と メカニズム』を 3 回担当した。この講義では, 上記に 述べた揚力の発生機構を中心に取り扱うが，幸いにも 流体運動は身の周りに幾らでも題材があることから講 義の中で多くの実験を採用し, ベルヌーイの定理の正 しい適用や誤った解釈を指摘しながら受講者の理解促 進に役立てた。さらに質点や流体の性質を一つ一つ実 験で確認しながら積み上げて, 最後に揚力発生の合理 的な説明をするための実験で締めくくる方式をとった ところ, 極めて大きな反響と効果が得られた。 そこで, 


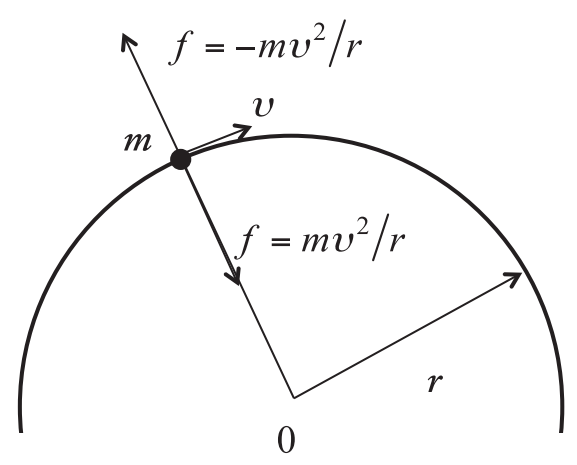

図 1 等速円運動する質点

講義内容の概略と講義終了に実施したアンケートの結 果を報告する．また，天秤の釣り合いをモーメントで はなくエネルギーの保存の観点から説明を行い, 意外 性を持つロバーバルの天秤を実演した結果とその反応 も合わせて報告する。

\section{2. 講義の概要}

\section{1 ニュートンカ学の質点運動}

身の周りの質点の運動はニュートン力学の 3 つの法 則（慣性，外力と加速度，作用と反作用）に支配され ている．今，紐に錘を付けて振り回し等速円運動をさ せる場合を考えてみよう。図 1 に示すように質点の質 量を $m$, 周速度を $v$, 回転半径を $r$ とする，等速運動 する質点は第 1 法則より, 等速直線運動を続けようと する. しかし紐によって外力が作用して質点の直線運 動は妨げられ，円運動を継続する。この外力を $f$, 質 点の加速度を $\alpha$ とするならば，第 2 法則より，

$$
f=m \alpha=m v^{2} / r
$$

となることは良く知られている。 この加速度の方向は 紐に沿うことから，外力は円運動の中心に向かい向心 力と呼ばれている. 一方, 質点には向心力と大きさは 等しいが，方向が逆の遠心力が発生している。この関 係は，作用・反作用から説明できる。ここまでの質点 の力学については, 概ね初学の学生といえども容易に 受け入れられるであろう。

さて, 質点の運動を支配する式 $f=m \alpha$ から, 自由に 変形する流体の運動に拡張されたEuler 方程式は, 図 2 のように定常で流線が湾曲した 2 次元流体運動を仮 定するならば，流線のベクトルを $\vec{s}(s=|\vec{s}|)$, 流線に沿う 速度を $q$, 流線と直角方向の単位べクトルを $\vec{n}$, 流線の 曲率半径を $r$ とし, その場の圧力を $p$ とするとき, 次の ように表せる。

流線に沿った運動方程式は：

$$
\frac{\partial p}{\partial s}=-\frac{\rho}{2} \frac{\partial q^{2}}{\partial s}
$$

流線と直角方向の力の釣り合い式：

$$
\frac{\partial p}{\partial n}=-\frac{\rho q^{2}}{r}
$$

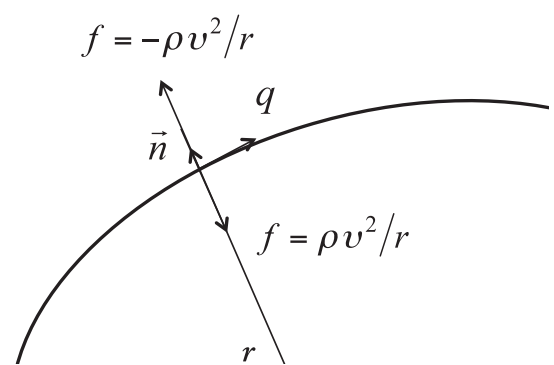

図 2 湾曲する流線に沿う流体粒子の運動

ただ，この式の導出は，些か煩雑であることから， 流線に沿う方程式と, それと直角方向の運動に分解し て導き出されるものとして，受け入れてもらう。(2) 式は，流線に沿って積分すると，良く知られたベルヌ 一イの定理が導かれる。一方, 流線と直角方向の釣り 合いの式 (3) は, 流体の場合圧力が質点の紐に相当し ていることが解る、すなわち, 流体が湾曲して等速運 動している場合, 質点の円運動と同様に流体は凸に湾 曲した方向に遠心力が発生する.この遠心力は, 流線 の凸側から凹面に向かう压力の勾配と鈞り合うことを 意味し, 圧力勾配は糸の働きをするわけである.

\section{2 ベルヌーイの定理}

良く知られたベルヌーイの定理は圧力, 流体の速度, その密度及び地表面からの高さを, それぞれ $p, u, \rho$, $z$ と記すとき，

$$
\frac{1}{2} u^{2}+\frac{p}{\rho}+g z=\text { const } .
$$

と書き下される. 圧力は大気のように流体が静止し ている場合の圧力を $\bar{p}$, 局所的な大気の静圧を $p^{\prime}$ と記せ ば (4) 式は，下記の 2 式に分離できる.

$$
\begin{aligned}
& \frac{\bar{p}}{\rho}+g z=c_{1} \\
& \frac{1}{2} u^{2}+\frac{p^{\prime}}{\rho}=c_{2} .
\end{aligned}
$$

(5) 式に熱力学の第一法則と状態方程式を適用すれ

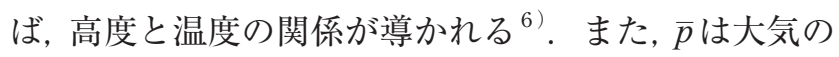
重みで生じたもので，1平方センチメートル当たりお およそ $1 \mathrm{~kg}$ であることは周知である. 机の縁に割り箸 の一部を突きだし，机に載せた箸を被うように新聞紙 を置いて突き出た割り箸に手を勢いよく振り下ろす. 勢いがないと箸と紙の間に隙間ができて, 空気が入り 紙は破れても箸は折れない. 空気が入らない程度に素 早く振り下ろすのがコツで, 紙はほとんど破れずにい とも簡単に箸は折れ，空気の重みを実感できる。この 実験で箸が折れた瞬間, 学生から自発的に拍手が湧い た。ささらに, 新聞紙を水で濡らした場合も試しに行う. 水で紙は机と密着するけれども, 紙の強度は極端に落 ちることから，今度は箸は折れずに紙が破れるだろう と, 大方の学生は予測していたようである。勢いよく 手を振り下ろすと, 新聞紙は無傷で見事に箸は折れ, 


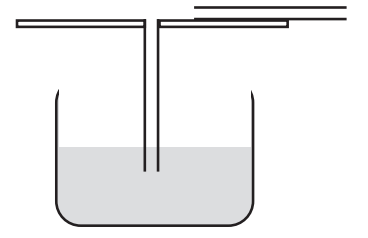

(a)平板に滑らか突き刺し たストロー

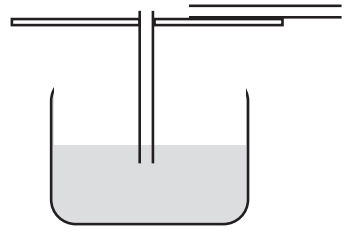

(b)ストロ一径の半分を平 板から突きだしたストロー

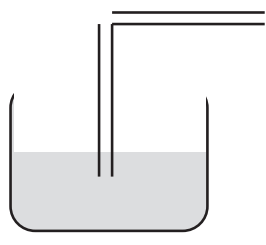

(c) 切れ目を入れて直角 に折り曲げたストロー

図 3 霧吹きの原理を理解するための実験装置

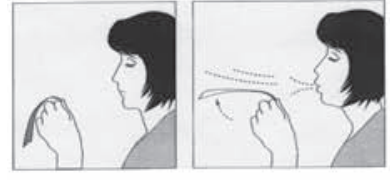

(a) 紙に息を吹きかけると紙 は吸い寄せられる》

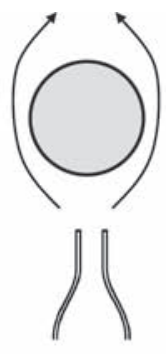

(b) 真上に吹き出した 噴流に安定に浮遊 するピンポン球

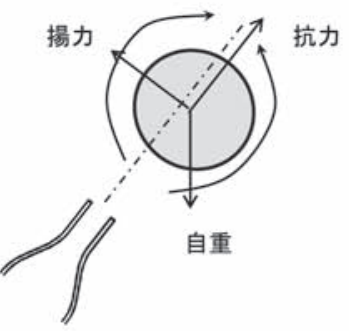

(c) 斜め上に噴流を吹き出す場 合, ピンポン球の自重で重 心位置が下がり，球の下面 より上面を回り込む流量が 増え, 揚力が発生して, ピン ポン球は安定に浮遊する

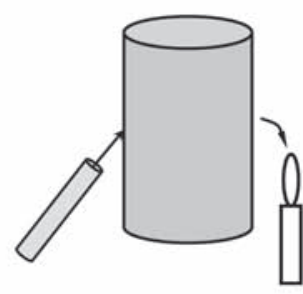

(d) 円筒を回り込む噴流で噴 流と反対側のろうそくの 火を消す

図 4 コアンダ効果と流線の湾曲

どよめく空気が読み取れる。

さて，(4) 式を確認するために流路を拡大・縮小さ せた簡単なラバール管を用意し，それぞれに静圧孔を 空けてパイプを取り付け，さらにパイプに着色水を入 れた透明ビニール管を慗いでU字形にして送風機から 流路に流れを送る実験を披露した。図解ではよく見か ける流れであるが，実際に目で確認したのは多くの学 生にとって初めてのようで, 129名の学生が解りやすい 実験であると賞賛している。次に，(4) 式が適用でき ない例を明示するとさらに効果的である。図 3 に示す ような霧吹きについての三通りの実験を行う。平板に 直角にストローを取り付け，平板に沿ってストロー上 端に息を吹きかけ，静圧が下がればコップに入れた着 色の水は吸い上げられ, 圧力の低下が確認できる仕組 みになっている。眓 $3 \mathrm{a}$ では空気を強く吹いても水は 一向に揚がらない. ストローから出た流れの静圧は直 ちに大気圧になるからである。ベルヌーイの定理を思 い浮かべたであろう30名の学生が, 意外な結果に驚き を表している.

ではストロー上端の圧力を下げ，水を吸い上げるた めにはどうすればよいであろうか. 図 $3 \mathrm{~b}$ のように空 気を吹き出すストローに対して水を吸い上げるストロ 一を直径の半分程度まで突き出したときが最も水は効 率よく吸い上げられる。強く吹けば, 水は優に $18 \mathrm{~cm}$ 以 上も吸い上げられ，水が霧状になるのを確認できる. その理由として次の 2 つの作用が考えられる. 吹き出
された流れはストローで妨害され，左右と上方に回り 込む. 左右を回り込む流れはストロー上端の圧力低下 にはほとんど貢献しないであろうが，ストロー上端に 回り达む流れはやや加速されて流線は大きく湾曲し, さらに湾曲した流れはストロー下流端で剥がれる，流 れの湾曲と剥離はストロー上端の圧力低下に貢献する であろう。その大雑把な割合を調べるために, 図 $3 \mathrm{c}$ のようにストローの中程にナイフで切り込みを入れて 直角に曲げ，流れがストロー上部で湾曲するのを防い だ. 結果としては, 幾ら強く空気を送り込んでも高々 水の上昇は $5 \mathrm{~cm}$ 程度であることから, 剥離による圧力 低下への貢献度は $3: 1$ 程度と見積もることができそ うである。この実験から式 (3) に示すように圧力の低 下に流線の湾曲と流れの加速が大きく貢献しているこ とが理解できる.

\section{3 コアンダ効果}

図 $4 \mathrm{a}$ のように紙を手で持ち, その端から空気を紙 に吹き付けると紙は流れに吸い寄せられる。この現象 もベルヌーイの定理で説明されることがあるが7), 明 らかに誤りである。図 $3 \mathrm{a}$ と同じように，口から吹き 出した流れの静圧は大気圧で, 紙が流れに吸い寄せら れるのは圧力の低下ではなくコアンダ効果のためであ る、紙の代わりに壁があると流れが壁に付着する。図 $4 \mathrm{~b}$ は鉛直に吹き出した円形噴流に浮遊するピンポン 玉で，噴流を左右前後に動かしても玉は安定に追従す る. 安定に浮遊する理由としてベルヌーイの定理で説 


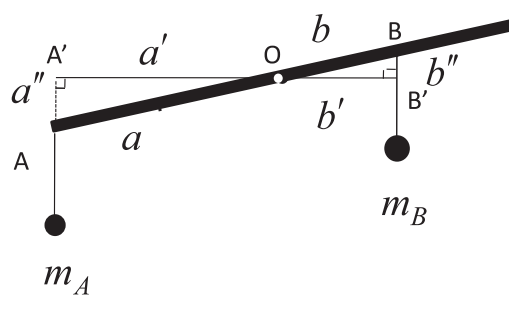

(a) 棹天科の斜めの釣り合い

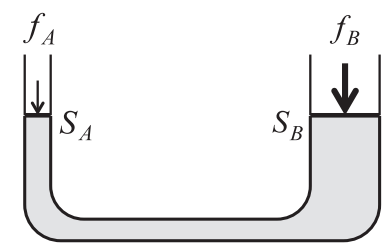

(b)連通管

図 5 棹天秤の釣り合いと連通管

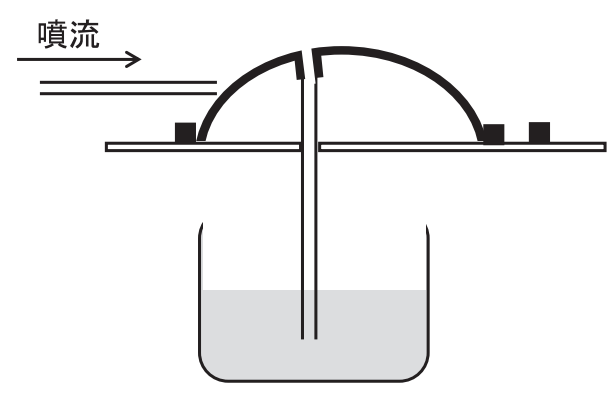

図 6 可撓性プラスッチック板で作る翼の 上面に沿う噴流
明されることがあるが,これも合理的な説明が難しく， むしろコアンダ効果と後述する流線の湾曲を用いると 驚くほど易しい説明ができる，吹き出しを斜めにして もピンポン玉は安定に浮遊する (図 $4 \mathrm{c}$ ). 理由は, 次 のように説明できる。ピンポン玉の重心位置は自重で 噴流中心から下方にずれるため, ピンポン玉の上部を 回り达む流量は下部より多くなり前記のコアンダ効果 と流線の湾曲の反作用から揚力が生じる．また，噴流 で作られる抗力, それにピンポン玉の自重で作る力の 平行四辺形が成り立ち, 揚力と抗力の水平成分が打ち 消し合ってピンポン球は吹き飛ばされずに安定に浮遊 する. 最も典型的なコアンダ効果の実験は図 $4 \mathrm{~d}$ に示 すように，円筒を用意し，ストローから円筒の接線方 向に吹き出して, 吹き出しと反対側に置いたローソク の火をいともた易く消す実験である４４割の学生がこ の実験に驚きを示している。

\section{4 天秤と連通管の釣り合い}

図 $5 \mathrm{a}$ のように棹天秤の釣り合いを考える。支点を $\mathrm{O}$ とし, 錘 $\mathrm{A}$ とBが釣り合っていれば, 三角形 $A O A^{\prime}$ と 三角形 $B O B^{\prime}$ は相似であることから，モーメントの釣 り合いから, $m_{A} a^{\prime}=m_{B} b^{\prime}$ である.ささらに相似の関係か ら, $m_{A} a^{\prime \prime}=m_{B} b^{\prime \prime}$ は明らかに成り立つ。この両辺に重力 加速度 $g$ を掛けて移項すると,

$$
-m_{A} g a^{\prime \prime}+m_{B} g b^{\prime \prime}=0
$$

この式 (7) の意味することは, 水平線 $A^{\prime} O B^{\prime}$ からの 2 つの錘の位置エネルギーの和が 0 となることである. また，天秤の棹の傾きによらないで，棹がどの位置で も常に釣り合いは保たれる訳である。

図 $5 \mathrm{~b}$ のような連通管の両脚の断面積を $S_{A}, S_{B}$ とし, これにそれぞれ $f_{A}$ と $f_{B}$ の力が加わって鈞り合っている とき

$$
\frac{f_{A}}{S_{A}}=\frac{f_{B}}{S_{B}}
$$

が成り立つことは良く知られている． $S_{A}$ に対して $S_{B}$ を 大きくすることで, $S_{B}$ に大きな力が取り出せ, 油圧機 構の基本原理である.式(8)の関係は一見不思議に思え るが，天秤の釣り合いと同じ考え方で導き出せる．管 内の流体の密度変化が無視でき, 釣り合っている $f_{A} に$ 僅かに力を加えたときの変位を下向きに $\delta_{A}$ とすると
き, $S_{B}$ の変位は上向きに $\delta_{B}$ とする. $f_{A}$ と $f_{B}$ の仕事は等 しいはずであるから, $f_{A} \delta_{A}-f_{B} \delta_{B}=0$ の関係が成り立 つ. また左右の変位した流量は等しいことから， $S_{A} \delta_{A}$ $-S_{B} \delta_{B}$ となって, 式 (8) が導ける. 結局, 天秤の支点 と錘までの距離が, 連通管の両脚の面積と対応してい る訳である。

\section{3. 揚力の発生機構と天秤の釣り合い}

\section{1 作用・反作用}

揚力の発生機構として, 前述した「同時到着理論」 に加えて, 作用・反作用がしばしば用いられる。この 解説は, 古くは文献 ${ }^{2)} に$ 見られるが, 揚力が発生して いる翼周りの流れの可視化写真を見れば明らかなよう に, 翼上面から後縁に向かって確かに流れは下方に押 し下げられているが, 後方に流れを押し下げた角度と 丁度符号が逆に翼前方の流れは翼に向かって吹き上げ られている ${ }^{3)}$. 従って, 翼の吹き下ろしで何ら運動量 の変化はないことを示している.

\section{2 流線曲率理論}

図 6 は，講義中に揚力発生を実演するために新規に 用意した模型である。 上面は A 4 版程度の可撓性の良 い薄い透明プラスチック板である。そのほぼ中央に静 圧孔が空けてあり，その静圧管にビニールチューブを 付けて, 着色した水の入ったコップに漬ける. 静圧が 下がれば着色水が揚がる仕組みである。

まずは，曲げないでプラスチック板を水平に保ち， その表面に沿って円形噴流を吹く，そこで, 実験の開 始前に「静圧は低くなるであろうか」と質問する．当 然のことながら, 静圧の変化が生じないことは図 3 の 実験で明白であるが，やはりベルヌーイの定理が頭に 浮かぶせいか, 多くの学生は, 水は吸い上げられると イメージするようである，次いで，板を蒲鉾状に曲げ 同様に表面に沿って円形噴流を吹く，今度は水は吸い 揚げられ，確かに静圧は低くなることを確認できる. さらに曲率を大きくして同様の実験を行う. 曲率半径 が小さくなれば，静圧がさらに低くなる訳である，質 点の円運動と全く同じアナロジーで説明できることが 解る. 式 (3) が示すように, 凸に湾曲した曲面に沿う 流れに対しては, 翼表面に向かう圧力勾配が生じ一様 


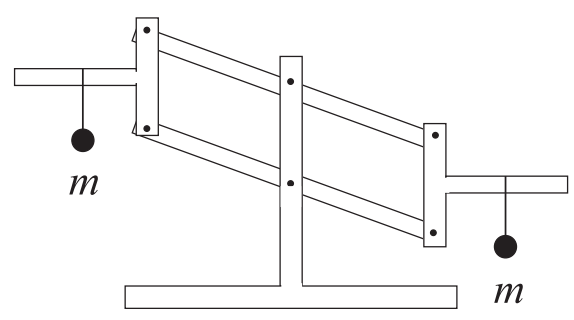

(a)鍾が左右対称位置で釣り合う天秤

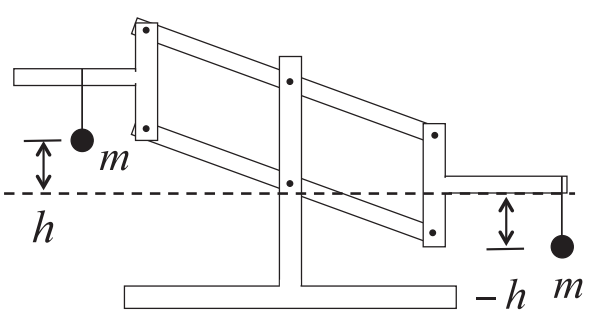

(b)錘の位置が左右異なる位置でも釣 り合う天秤. 波線は仮想の水平基準線

図 7 ロバーバルの天秤. リンクの小黒点はピン

流れの静圧に比べて翼表面は压力が低下し揚力の発生 が生じる. 結果として, 式 (2)のベルヌーイの定理に 従って, 圧力が低下した翼面に沿って流れが加速され る，と説明できる。

\section{3 ロバーバルの天秤}

流体運動あるいは質点運動を取り扱う上で, 力の釣 り合いを考えるべきか，あるいはエネルギー保存式を 使うべきかは, 状況によって使い分ける必要がある. 揚力発生機構は, エネルギー保存式より力の釣り合い を用いた方がより合理的に説明できた例である．天秤 の釣り合いを考える場合は，前者より後者が遙かに勝 っている好例を紹介しょう。

図 7 は1670年代にフランスの数学者ロバーバル （Roberval, G.P.de., 1602-1675）が考案した天秤で, この原理は上血天秤機構として広く日常生活で使われ ている. 発明したロバーバル自身はその機構原理を証 明できず，抒抒よそ一世紀以上経ってようやく説明さ れた難しいリンク機構である. 平行四辺形の上辺と下 辺の中点は鉛直棒のピンに掛けられ，また平行四辺形 の四隅はピンで接続され, 平行四辺形は自由な動きが 可能である. さらに, 平行四辺形の左右の辺中央に長 さが同じ水平棒が取り付けられている。学生には, 上 皿天秤に使われた機構であることを伏せておき，まず 実演で錘が水平棒のどの位置でも天秤は平衡を保つこ とを示し, 驚きを与える. 次に学生にはこの問題をど のように考えたら良いか問いかける。この実験の前に 前記図 5 を用いながら位置エネルギーを用いた棹天科 の釣り合いの説明をしておいても, 多くの学生は『錘 と腕の長さを掛けたモーメント』の䶸縛から抜け出せ ないようである。しかし，モーメントを使うとどう考 えても簡単に解決に結び付かない.インターネットや 文献調查でその解法を調べると, 全てモーメントを使 っていて，甚だその式も複雑であり ${ }^{8)}$. 筆者自身もそ の式を追求する気も起こらないほどである.

さて前置きはここまでとし，もっとスマートな説明 が求められる。このリンク機構に着目すると, 平行四 辺形の左右の縦棒に錘を垂らす水平棒が直角に固定さ れていることから, 平行四辺形の傾きによらず水平棒 は常に水平を保つ。それ故, 図 $7 \mathrm{~b}$ のように左右の錘
の中間に波線で示した仮想の水平線を引けば, その水

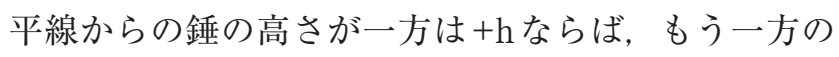
錘の高さは-hである. 錘の高さは, 水平棒のどの位置 に置いても一定である.すなわち, 式 (7) に示すとお り, 左右の錘の位置エネルギーの和は常に 0 が保たれ る. また, リンク機構の平衡点を変えても, 仮想水平 線からの高さの和は常に 0 となり, やはりリンク機構 は平衡を保つはずである.

\section{4. 結び}

講義終了時に，選択形式のアンケートを実施し，ほ ぼ受講者全員に当たる168名から回答を得た。項目は

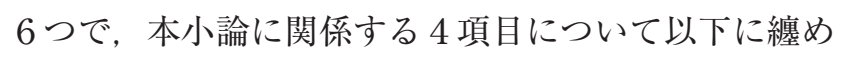
る.

講義に実験を取り入れることに対して,「大いに歓迎 する」あるいは「歓迎する」を選んだ学生は166名で, そのうち前者が120名であった。また，実験を取り入れ ることで流体力学の理解度が「大いに深まった」と「深 まった」学生は148名であった，以上のように学生は講 義に実験を取り入れることを心より歓迎し, その効果 も大いに期待できることが明らかとなった. 講義内で 実験を10種以上行った。これらの実験に対して結果が 意外であったものについて複数を許して選ばせた。 そ の上位は，ロバーバルの天秤が97名で，予想通りであ った. 次いで斜め噴流に安定して浮遊するピンポン球 と新聞紙で抑えた割り箸が折れた実験について，ほほ 半数の学生が意外性を感じている. 箸が折れた瞬間の 学生の拍手は, 最初の実験であったことも関係するで あろうが,「まさか折れるとは」という驚きを感じた意 思表示と思えた，霧吹きの原理と揚力の発生の説明に ベルヌーイの定理の適用が難しいことに対して，いず れも61名の学生が驚きを表している. 広まっている通 説の影響ではないかと考えられる。

今回の講義の主目的であった揚力の発生機構につい て, 流線の曲りからの説明に納得した学生は 6 割弱, 「納得できない」が13名,「解らない」が46名,「もっ と旨い説明がありそう」が 9 名であった。解らないと 答えた46名の学生の大半は, 式を十分追いきれていな いことがアンケートからも伺えた。ささらに平易で解り 
やすい説明が求められていることを痛感した次第であ る.

最後に, 講義で実験を行っている最中に寝ている学 生が一人もいないのには，些か驚かされる。この実験 では予想通りの結果が得られるのか, それとも意外な 結果に終わるのか, 大げさに言えば固唾をのんでいる ように見える.最後に行った揚力が発生する実験では, 学生の一番暑い視線を感じた. 教師の醍醐味を味わっ た瞬間であった。

\section{謝辞}

講義演壇で行う実験状況を後部の学生にも見えるよ うビデオカメラで撮影し, 大スクリーンに映し出した. そのために, カメラと三脚の購入を大学当局より支援 頂いた。ここに感謝を申し上げたい. また，日本大学 名誉教授の藤田肇氏からは，本稿投稿にあたり内容に 関して貴重なご意見を頂きました。ここに感謝の意を 表します。

\section{参 考 文 献}

1）今井 功, 他: 続 物理の散歩道, 岩波書店, pp.157 $-162,1971$

2）今井 功：電子対発生と揚力, 岩波講座 現代物理 学の基礎 月報, 9 月, pp. $1-3,1972$

3 ）日本機械学会:流れ-写真集, 丸善, pp.70-77, 1984

4 ）高木正平：なぜ翼に揚力が発生するか? -ベルヌ
一个の定理か流線曲率の定理か-, 日本機械学會 誌, $113-1097$, pp.262-265, 2010

5 ）高木正平 : 流線の曲りから揚力発生機構を説明す る試み, 日本航空宇宙学会誌, 58-672, pp.30-32, 2010

6 ）高木正平 : 飛行機に乗って体験した高度と気温の 関係, 日本航空宇宙学会誌, 57-668, pp.272-273, 2009

7 ）中村寛治：面白いほどよくわかる飛行機のしくみ, 日本文芸社, 2007

8 ）例えば鈴木 勲：上血天秤の釣り合いの機構ロバーバル機構 -, 化学教育, 34-4, pp.339-340, 1986

著者紹介

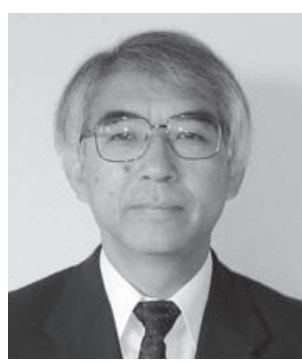

高木 正平

東京大学工学系研究科卒業. 工学博士. 1979年東京大学宇宙科学研究所助手, 同年 9 月航空宇宙技術研究所転任. 1995年同研 究所空力性能部室長. 2002年流体科学研究 センター長. 2009年 3 月 JAXA 停年退職, 同年 4 月室蘭工業大学航空宇宙機システ ム研究センター教授. 専門は乱流遷移と制 御, 航空力学. 日本流体力学会, 日本航空 宇宙学会, 米国航空宇宙学会に所属 連絡先：pantaka@mmm.muroran-it.ac.jp 